Med Klin Intensivmed Notfmed 2018 113 (Suppl 1):S2-S6

https://doi.org/10.1007/s00063-017-0376-8

Received: 12 June 2017

Accepted: 14 October 2017

Published online: 7 November 2017

๑) Springer Medizin Verlag GmbH 2017

\section{Redaktion}

M. Quintel, Göttingen

L. Gattinoni, Milan

CrossMark

\section{F. F. Cruz • P. R. M. Rocco' ${ }^{1}$ P. Pelosi ${ }^{2}$}

'Laboratory of Pulmonary Investigation, Carlos Chagas Filho Institute of Biophysics, Federal University of Rio de Janeiro, Rio de Janeiro, Brazil

${ }^{2}$ Department of Surgical Sciences and Integrated Diagnostics, Ospedale Policlinico San Martino, IRCCS for Oncology, University of Genoa, Genoa, Italy

\title{
Role of the extracellular matrix in the genesis of ventilator-induced lung injury
}

\section{Introduction}

Alveolar wall integrity is crucial for the adequate maintenance of gas exchange between blood and air. It also provides a mechanical framework, protects from fluid overload, and enables interactions between different cells [1].

\section{The extracellular matrix organization}

In the gas-exchange region of the lung, the extracellular matrix (ECM) represents the three-dimensional scaffold of the alveolar wall, which is composed of basement membranes and a thin layer of non-cellular interstitial space lying between the capillary endothelium and the alveolar epithelium [1]. The alveolar extracellular matrix is mainly composed of fibrous proteins (collagen and elastin), glycoproteins (fibronectin and laminin), glycosaminoglycans (GAGs), and proteoglycans (PGs) (- Fig. 1a, [2-4]). The ECM is a dynamic structure, and equilibrium between synthesis and degradation of its components is required for homeostasis. Although many proteases are able to cleave ECM molecules, the family of matrix metalloproteinases (MMPs) are likely to be the normal, physiologically relevant mediators of degradation of ECM components [4]. Many ECM

Authors' contributions. F.F. Cruz, P.R.M. Rocco, P. Pelosi contributed to the literature review and the drafting of the manuscript. All authors read and approved the final manuscript. functions are well described, but the role of ECM components in the pathogenesis of ventilator-induced lung injury (VILI) needs to be better clarified [2].

\section{The ECM during mechanical ventilation}

Mechanical ventilation has become an indispensable tool in medicine, facilitating general anesthesia and supporting life in critically ill patients. Compared to spontaneous breathing, controlled mechanical ventilation presents reversed distribution of intrathoracic pressures, increased transpulmonary pressure, inhomogeneous distribution of ventilation, and reduced lymphatic drainage, which altogether can promote extracellular matrix rupture and progressive lung injury [5].

Some authors have shown that ventilation under physiologic tidal volumes $(6-8 \mathrm{ml} / \mathrm{kg})$ for a few hours induces proteoglycan fragmentation from the alveolar septa, which is not associated with activation of systemic or tissue MMPs, lung edema, inflammation, or collagen fiber deposition $[2,6]$.

\section{The ECM and ventilator-induced lung injury}

It is well known that mechanical ventilation can cause lung damage, which is known as ventilator-induced lung injury (VILI) [7]. Several studies have shown that mechanical ventilation with low tidal volumes $\left(\mathrm{V}_{\mathrm{T}}\right)$ may cause damage to the peripheral airways and interstitium in healthy lungs $[8,9]$, due to abnormal stresses derived from cyclic opening and closing of peripheral airways at low endexpiratory lung volume, a phenomenon known as atelectrauma $[8,9]$. On the other hand, excessive inspiratory airway pressure with increased transpulmonary pressures is associated with overdistension and mechanical stress, known as barotrauma, which can in turn cause damage to the ECM and endothelial and epithelial cells, resulting in an exacerbated inflammatory response and/or inactivation of surfactant (- Fig. 1b, c, [10]).

Mechanical ventilation with low and high $\mathrm{V}_{\mathrm{T}}$ can lead to proteoglycan and glycosaminoglycan fragmentation [11], which triggers activation of the inflammatory process, leading to alveolar edema and collagen deposition (- Fig. 2), the main features of VILI [7, 12]. Moriondo et al. reported marked fragmentation of interstitial and basal membrane proteoglycans in anesthetized rats ventilated for $4 \mathrm{~h}$ at a $\mathrm{V}_{\mathrm{T}}$ of $7 \mathrm{ml} / \mathrm{kg}$ [7]. Recently, breathing patterns induced by different anesthetic regimens were shown to trigger disorganization and/or remodeling of the ECM. An anesthetic mixture of pentobarbital/urethane led to fragmentation of heparan sulfate (HS) and chondroitin sulfate (CS) [13]. In addition, at low $\mathrm{V}_{\mathrm{T}}$, application of positive end-expiratory pressure (PEEP) seems to be protective [14], mainly in the ventral lung regions [15], reducing disruption of GAGs and PGs [14, 15]. On the other hand, $\mathrm{Al} \mathrm{Jamal} \mathrm{et} \mathrm{al.} \mathrm{showed}$ 


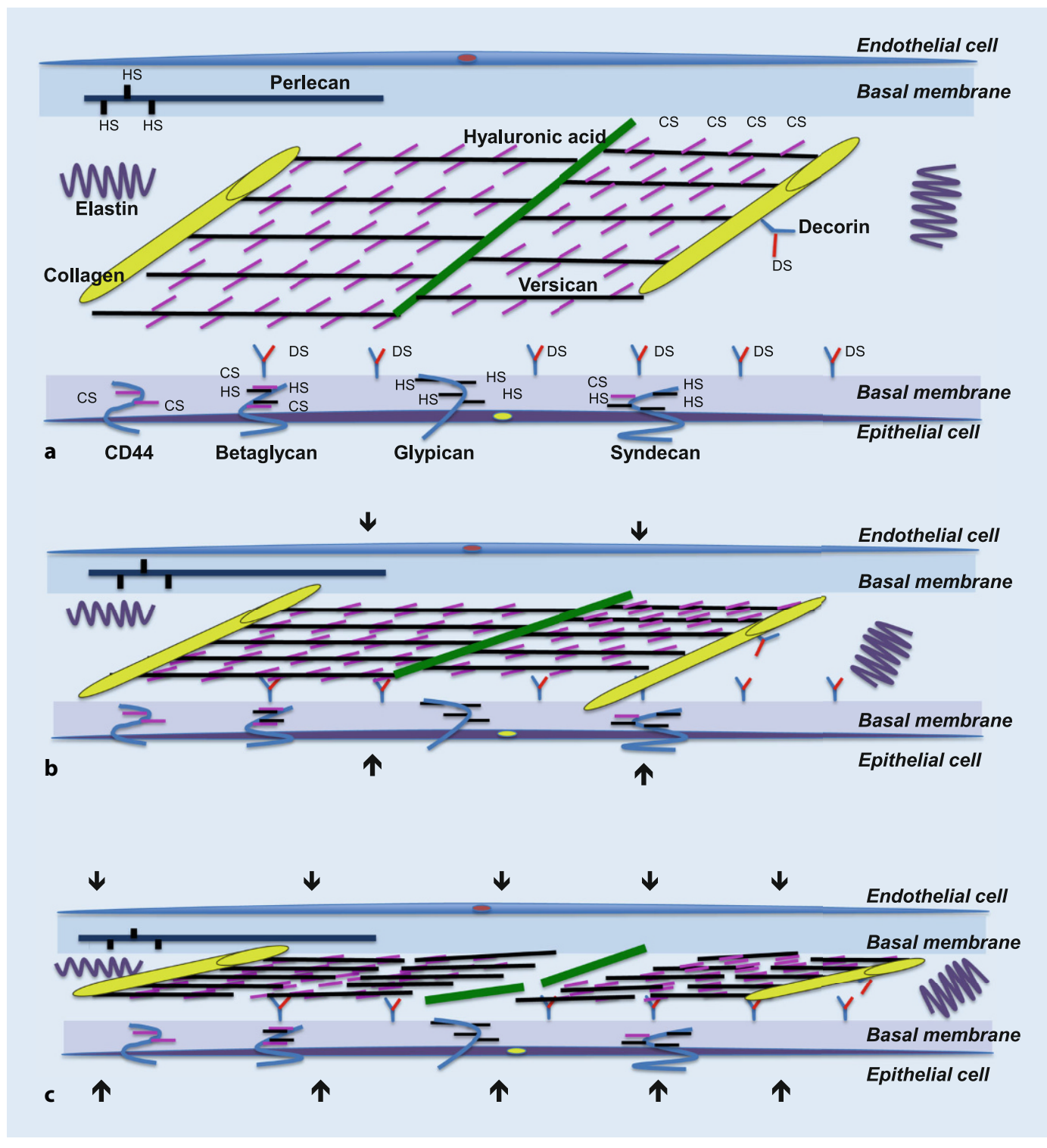

Fig. 1 Extracellular matrix organization. a End of expiration. The alveolar septa are limited by endothelial and epithelial cells anchored in their basal membrane. The main acellular components are collagen and elastin fibers, glycoproteins, proteoglycans (PG), and glycosaminoglycans (GAGs), such as CS (chondroitin sulfate), DS (dermatan sulfate), and HS (heparan sulfate). PGs shown in this figure: Perlecan (HS-PG), CD44 (CS-PG), betaglycan (CSHS-PG), glypican (HS-PG), syndecan (CS-HS-PG), and decorin (DS-PG). $\mathbf{b}$ End of inspiration: reorganization of the extracellular matrix. c End of inspiration during mechanical ventilation with high intrapulmonary pressures: fragmentation of interstitial components of the extracellular matrix

that extremely high $\mathrm{V}_{\mathrm{T}}(30 \mathrm{ml} / \mathrm{kg})$ and high respiratory rate ( 90 breaths/minute) induce the expression of versican (CSPG), basement membrane HS-proteoglycan (HS-PG), and biglycan in lung tissue [16]. Moriondo et al. also observed CS and HS fragmentation at high $\mathrm{V}_{\mathrm{T}}$ [6] and showed that the fluid overload associated with high- $\mathrm{V}_{\mathrm{T}}$ mechanical ventilation worsened GAG fragmentation, mainly in the ventral lung regions [13].

Fragmented PGs modify the pulmonary inflammatory response and leukocyte migration through several mechanisms, including (1) the ability of soluble PGs or GAG fragments to activate Toll-like receptor signaling pathways and downstream secretion of pro- inflammatory mediators; (2) their highly specific binding, sequestration, and interaction with cytokines, chemokines, and growth factors; (3) the ability of PGs and hyaluronan to facilitate leukocyte adhesion and sequestration; and (4) the interactions between $\mathrm{PGs}$ and matrix MMPs, which alter the function of these proteases [2, 4]. Therefore, fragmentation of GAGs and breakdown of PGs may have an impact on the development of the inflammatory response seen in VILI. In this context, PG levels in blood have been analyzed in the search for a potential early marker of injury. Endocan, a DS-PG synthesized and secreted by endothelial cells, is metabolized mainly by proteases throughout the lung and by inflammatory cells. Endocan levels are increased in the serum of patients with ARDS, pneumonia, and septic shock, and any increase of this PG in serum is a surrogate marker of worsening clinical course towards organ dysfunction [17, 18]. Thus, analysis of PG fragments from the basal membrane of the alveolar epithelium and endothelium and from the interstitium might be helpful in the near future as early phase markers of lung injury in previously uninjured or injured lungs.

There is increasing evidence that cyclic mechanical stress affects the release and activation of MMPs and plays an important role in the regulation of ECM remodeling. MV with physiologi- 
Med Klin Intensivmed Notfmed 2018 113 (Suppl 1):S2-S6

https://doi.org/10.1007/s00063-017-0376-8

(c) Springer Medizin Verlag GmbH 2017

\section{F. F. Cruz · P. R. M. Rocco $\cdot$ P. Pelosi}

\section{Role of the extracellular matrix in the genesis of ventilator- induced lung injury}

cal $\mathrm{V}_{\mathrm{T}}$ induces increased expression and activity of MMP-2 and MMP-9 over time [13], while high $\mathrm{V}_{\mathrm{T}}$ induces increased expression and release of MMPs by macrophages and epithelial and endothelial cells in response to mechanical stress [6]. Moreover, Foda et al. observed that MMPs play an important role in the development of VILI in an in vivo rat model of high-volume ventilation [19]. In this context, some groups have been studying treatment strategies that inhibit MMP activity, with promising results [19].

Matrikines, peptides originating from the fragmentation of ECM proteins, should also be considered to explain part of VILI pathophysiology. [2, 20]. Elastin matrikines can lead to expression and activation of MMP-1 and MMP-3 in human fibroblasts (which, in turn, worsens lung damage) and increase MMP2 and MMP-3 (which, in turn, degrade more elastin). Thus, breakdown of ECM proteins caused by high $\mathrm{V}_{\mathrm{T}}$ results in an exposure of matrikines, which can then act as ligands to induce subsequent biologic effects, including remodeling and inflammatory processes [20].

Mechanical stretch can modify the gene expression of several molecules associated with remodeling and inflammatory processes [21-23]. Ventilation with high $\mathrm{V}_{\mathrm{T}}$ and airway pressure, as well as transpleural gradients, initiates ECM remodeling [6]. Berg et al. found that high lung inflation due to high PEEP levels increased mRNA expression of procollagen, fibronectin, and profibrogenic growth factors [24]. Parker et al. found that ventilation with high peak airway pressures and low perfusion pressures led to greater type III procollagen mRNA expression than in unperfused lungs [25]. Garcia et al. demonstrated that the increase in the tissue stress induced by oscillation force, but not amplitude, increases type III procollagen mRNA expression in rat lung parenchymal strips [26]. Furthermore, Farias et al. showed that lung mechanical stretch $\left(40 \mathrm{cmH}_{2} \mathrm{O}\right.$ of continuous positive airway pressure), even during a short period $(40 \mathrm{~s})$, results in type III procollagen mRNA expression [27]. Along these lines, De Carvalho et al. showed that ventilator strategies

\begin{abstract}
The extracellular matrix represents the threedimensional scaffold of the alveolar wall, which is composed of a layer of epithelial and endothelial cells, their basal membrane, and a thin interstitial layer containing fibrous proteins, glycoproteins, glycosaminoglycans, and proteoglycans. Mechanical ventilation with low and high tidal volumes can induce proteoglycan fragmentation, which may cause activation of the inflammatory cascade, leading to the main features of ventilatorinduced lung injury (VILI): alveolar edema and collagen deposition. The purpose of this article is to describe VILI pathophysiology
\end{abstract}

\section{Rolle der extrazellulären Matrix in der Entstehung des beatmungsinduzierten Lungenschadens}

Zusammenfassung

Die extrazelluläre Matrix bildet das dreidimensionale Gerüst der Alveolenwand, die aus einer Schicht von Epithel- und Endothelzellen, ihrer Basalmembran und einem dünnen Interstitium mit Faserproteinen, Glykoproteinen, Glykosaminoglykanen und Proteoglykanen besteht. Die Beatmung mit niedrigen und hohen Atemzugvolumina kann eine Fragmentierung der Proteoglykane auslösen, die wiederum eine Aktivierung der Entzündungskaskade bewirken kann. In der Folge entwickeln sich die Hauptmerkmale des beatmungsinduzierten Lungenschadens: alveoläres Ödem und Kollagenablagerung. Im vorliegenden Beitrag soll die Pathophysiologie des beatmungsinduzierten with a special focus on the effects of mechanical ventilation on the extracellular matrix. A more complete understanding of the molecular effects induced by physical forces is required to better assess the impact of existing mechanical ventilation strategies, as well as to develop new therapeutic strategies to reduce lung damage.

\section{Keywords}

Extracellular matrix $\cdot$ Ventilator-induced lung injury - Mechanical ventilation - Respiration, artificial $\cdot$ Pulmonary alveoli associated with overdistension caused an increase in type III procollagen expression, mainly in non-dependent regions, a response that was partially attenuated by prone positioning [28]. This suggests an effect of regional transpleural pressures that emerged due to lung heterogeneity in the context of VILI.

\section{Practical conclusion}

The primary event during protective mechanical ventilation is GAG degradation/remodeling, which activates lung injury and inflammatory response. Dur-
Lungenschadens erläutert werden. Ein Schwerpunkt liegt dabei auf den Auswirkungen der Beatmung auf die extrazelluläre Matrix. Wir müssen die molekularen Effekte physikalischer Kräfte genauer verstehen, wenn wir die Auswirkungen der verfügbaren Beatmungsverfahren gründlicher bestimmen und neue Therapiestrategien zur Verringerung von Lungenschäden entwickeln wollen.

\section{Schlüsselwörter}

Extrazelluläre Matrix · Beatmungsinduzierter Lungenschaden - Mechanische Beatmung · Künstliche Beatmung · Lungenalveolen ing mechanical ventilation, reversed distribution of intrathoracic pressures, increased transpulmonary pressure, inhomogeneous distribution of ventilation, and reduced lymphatic drainage can, together, promote ECM rupture and progressive lung injury. Damage to pulmonary GAGs is worse during controlled MV as compared to spontaneous breathing, mainly in the dependent regions of the lung. PEEP is protective on pulmonary GAGs during MV, independent of tidal volume. Excessive administration of fluids can induce ECM injury. Further research is required to elucidate 


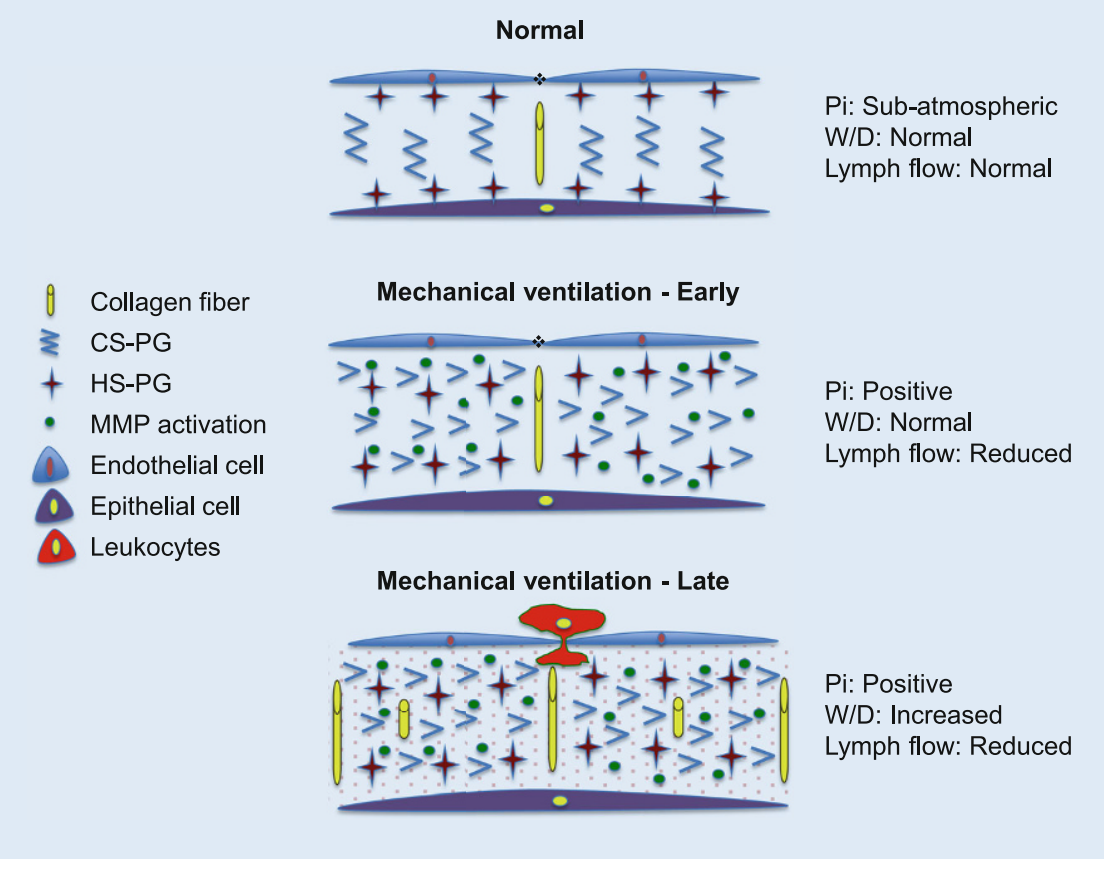

Fig. $2 \Delta$ Early and late phase changes in the extracellular matrix during mechanical ventilation (MV). $P i$ interstitial pressures, W/D wet-to-dry ratio, CS chondroitin sulfate, $H S$ heparan sulfate, $P G$ proteoglycan; MMP matrix metalloproteinases. The early phases of MV are characterized predominantly by GAG and PG fragmentation, which triggers the inflammatory process, and activation of MMPs. This is followed by injury to the alveolar capillary membrane, collagen deposition, alveolar and interstitial edema, and ARDS

\section{the mechanisms of VILI and the role of ECM in this mode of lung injury.}

\section{Corresponding address}

\section{P. Pelosi, MD, FERS}

Department of Surgical Sciences and Integrated Diagnostics, Ospedale Policlinico San Martino, IRCCS for Oncology, University of Genoa

Genoa, Italy

ppelosi@hotmail.com

Funding. Publication costs were funded by the Department of Surgical Sciences and Integrated Diagnostics (DISC), University of Genoa, Genoa, Italy. This study was supported by the Carlos Chagas Filho Rio de Janeiro State Research Foundation (FAPERJ; grant number E-26/103.118/2014), Rio de Janeiro, Brazil; and the Brazilian Council for Scientific and Technological Development (CNPq; grant number 471438/2012-0, 469716/2014-2, 465064/2014-0, and 400462/2014-1 to PRMR), Brasília, Brazil.

Conflict of interest. F. F. Cruz, P. R. M. Rocco and P. Pelosi declare that they have no competing interests.

The supplement containing this article is not sponsored by industry.

\section{References}

1. White ES (2015) Lung extracellular matrix and fibroblast function. Ann Am Thorac Soc 12(Suppl 1):S30-S33

2. Pelosi P, Rocco PRM, Negrini D, Passi A (2007) The extracellular matrix of the lung and its role in edema formation. An Acad Bras Cienc 79(2):285-297

3. Mouw JK, Ou G, Weaver VM (2014) Extracellular matrix assembly: a multiscale deconstruction. Nat Rev Mol Cell Biol 15(12):771-785

4. Gill S, Wight TN, Frevert CW (2010) Proteoglycans: key regulators of pulmonary inflammation and the innate immune response to lung infection. Anat Rec (Hoboken) 293:968-981

5. Pelosi P, Roco PRM (2008) Effects of mechanical ventilation on the extracellular matrix. Intensive Care Med 34(4):631-639

6. Moriondo A, Pelosi P, Passi A, Viola M, Marcozzi C, Severgnini P,Ottani V, Quaranta M, Negrini D (2007) Proteoglycans fragmentation and respiratory mechanics in mechanically ventilated healthy rats. J Appl Physiol 103:747-756

7. Curley GF, Laffey JG, Zhang H, Slutsky AS (2016) Biotrauma and ventilator-induced lung injury: clinical implications. Chest 150(5):1109-1117

8. D'Angelo E, Pecchiari M, Della Valle P, Koutsoukou A, Milic-Emili J (2005) Effects of mechanical ventilation at low lung volume on respiratory mechanics and nitric oxide exhalation in normal rabbits. J Appl Physiol 99:433-444

9. D'Angelo $E$, Pecchiari $M$, Saetta $M$, Balestro $E$, Milic-Emili J (2004) Dependence of lung injury on inflation rate during low-volume ventilation in normal open-chest rabbits. J Appl Physiol 97:260-268

10. Silva PL, Negrini D, Rocco PR (2015) Mechanisms of ventilator-induced lung injury in healthy lungs. Best Pract Res Clin Anaesthesiol 29(3):301-313

11. Souza-Fernandes AB, Pelosi P, Rocco PRM (2006) Bench-to-bedside review: the role of glycosaminoglycans in respiratory disease. Crit Care 10(6):237

12. Ludwig M (2007) Proteoglycans and pathophysiology. J Appl Physiol 103:735-736

13. Moriondo A, Marcozzi C, Bianchin F, Passi A, Boschetti F, Lattanzio S, Severgnini P, Pelosi P, Negrini D (2011) Impact of respiratory pattern on lung mechanics and interstitial proteoglycans in spontaneously breathing anaesthetized healthy rats. Acta Physiol (Oxf) 203(2):331-341

14. Moriondo A, Marcozzi C, Bianchin F, Reguzzon $M$, Severgnini $P$, Protasoni $M$, Raspanti $M$, Passi A, Pelosi P, Negrini D (2012) Impact of mechanical ventilation and fluid load on pulmonary glycosaminoglycans. Respir Physiol Neurobiol 181(3):308-320

15. Marcozzi C, Moriondo A, Solari E, Reguzzoni M, Severgnini P, Protasoni M, Passi A, Pelosi P, Negrini D (2015) Regional lung tissue changes with mechanical ventilation and fluid load. Exp Lung Res 41(4):228-240

16. Al Jamal R, Ludwig MS (2001) Changes in proteoglycans and lung tissue mechanics during excessive mechanical ventilation in rats. Am J Physiol Lung Cell Mol Physiol 281:L1078-L1087

17. loakeimidou A, Pagalou E, Kontogiorgi M, Antoniadou E, Kaziani K, Psaroulis K, GiamarellosBourboulis EJ, Prekates A, Antonakos N, Lassale P, Gogos C, Hellenic Sepsis Study Group (2017) Increase of circulating endocan over sepsis followup is associated with progression into organ dysfunction. Eur J Clin Microbiol Infect Dis. https:// doi.org/10.1007/s10096-017-2988-6

18. Gaudet A, Chenevier-Gobeaux C, Parmentier $E$, Delobel JE, Dubucquoi S, Mathieu D, Lassalle $\mathrm{P}$ De Freitas Caires N (2017) Endocan is a stable circulating molecule in ICU patients. Clin Biochem. https://doi.org/10.1016/j.clinbiochem.2017.04. 011

19. Foda HD, Rollo EE, Drews M (2001) Ventilatorinduced lung injury upregulates and activates gelatinases and EMMPRIN: attenuation by the synthetic matrix metalloproteinase inhibitor, prinomastat (AG3340). Am J Respir Cell Mol Biol 25:717-724

20. Wells JM, Gaggar A, Blalock JE (2015) MMP generated matrikines. Matrix Biol. https://doi.org/ 10.1016/j.matbio.2015.01.016

21. Pittet JF, Griffiths MJ, Geiser T, Kaminski N, Dalton $\mathrm{SL}$, Huang $X$, Brown LA, Gotwals PJ, Koteliansky VE, Matthay MA, Sheppard D (2001) TGF-beta is a critical mediator of acute lung injury. JClin Invest 107:1537-1544

22. Schild C, Trueb B (2002) Mechanical stress is required for high-level expression of connective tissue growth factor. Exp Cell Res 274:83-91

23. Frank J, Roux J, Kawakatsu H, Su G, Dagenais A, Berthiaume Y, Howard M, Canessa CM, Fang X, Sheppard D, Matthay MA, Pittet JF (2003) Transforming growth factor-beta1 decreases expression of the epithelial sodium channel alphaENaCand alveolar epithelial vectorial sodium and fluid transport via an ERK1/2-dependent mechanism. J Biol Chem 278:43939-43950

24. Berg JT, FuZ, Breen EC, Tran HC, Mathieu-Costello O, West JB (1997) High lung inflation increases mRNA levels of ECM components and growth factors in lung parenchyma. J Appl Physiol 83:120-128 
25. Parker JC, Breen EC, West JB (1997) High vascular and airway pressures increase interstitial protein mRNA expression in isolated rat lungs. J Appl Physiol 83:1697-1705

26. Garcia CS, Rocco PR, Fachinetti LD, Lassance RM, Caruso P, Deheinzelin D, Morales MM, Romero PV, Faffe DS, Zin WA (2004) What increases type III procollagen mRNA levels in lung tissue: stress induced by changes in force or amplitude? Respir Physiol Neurobiol 144:59-70

27. Farias LL, Faffe DS, Xisto DG, Santana MC, Lassance R, Prota LF, Amato MB, Morales MM, Zin WA, Rocco PR (2005) Positive end-expiratory pressure prevents lung mechanical stress caused by recruitment/derecruitment. J Appl Physiol 98:53-61

28. de Carvalho ME, Dolhnikoff $M$, Meireles SI, Reis LF, Martins MA, Deheinzelin D (2007) Effects of overinflation on procollagen type III expression in experimental acute lung injury. Crit Care 11:R23

\section{SpringerMedizin.de Lesen Sie Ihre Fachzeitschrift auch als ePaper!}

Als Abonnent können Sie Ihre Zeitschrift in verschiedenen Formaten lesen. Wählen Sie je nach Vorliebe und Situation aus, ob Sie die Zeitschrift als Print-Ausgabe, in Form von einzelnen Beiträgen auf springermedizin.de oder aber als komplette, elektronische ePaper-Ausgabe lesen möchten.

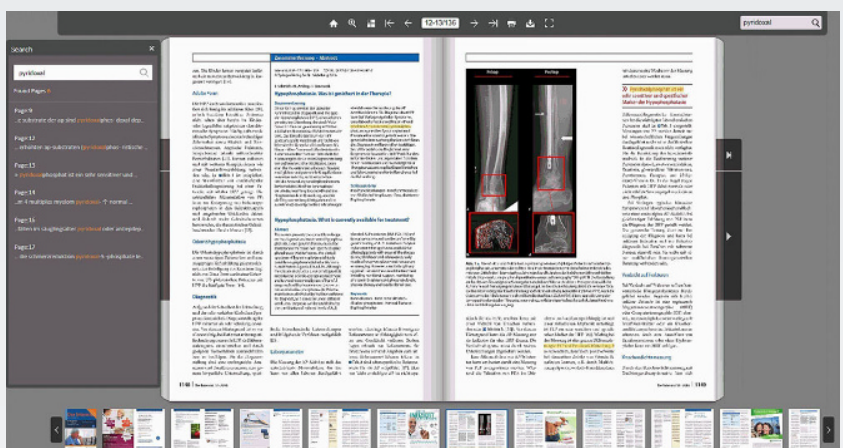

Die ePaper sind die identische Form der gedruckten Ausgaben. Sie sind nutzbar auf verschiedenen Endgeräten wie PC, Tablet oder Smartphone

Das sind die Vorteile des ePapers:

> Das verlinkte Inhaltsverzeichnis führt Sie direkt zum gewünschten Beitrag.

> Eine Suchfunktion ermöglicht das Auffinden von Schlagworten innerhalb der Zeitschrift.

$>$ Jede Ausgabe kann als PDF heruntergeladen und damit auch offline gelesen werden bzw. auch gespeichert oder ausgedruckt werden.

> Als Abonnent haben Sie Zugang zu allen ePaper-Ausgaben ab 2016.

Sie finden die ePaper auf SpringerMedizin.de bei der jeweiligen Ausgabe Ihrer Fachzeitschrift. Klicken Sie auf den Button „Ausgabe als ePaper lesen“. 